\title{
Risk Assessment and Chemical Fractionation of Heavy Metals by BCR Sequential Extraction in Soil of the Sapanca Lake Basin, Turkey
}

\author{
Asude Ates ${ }^{1 *}$, Hulya Demirel ${ }^{2}$, Nihan Mergul ${ }^{1}$ \\ ${ }^{1}$ Faculty of Engineering, Environmental Engineering Department, Sakarya University, Turkey \\ ${ }^{2}$ Sakarya Vocational School, Environmental Protection Technology Department, \\ Sakarya University of Applied Science, Turkey
}

Received: 20 July 2018

Accepted: 15 December 2018

\begin{abstract}
Sapanca Lake is an important drinking water source located by D-100 highway in the north and E-80 (TEM Anatolian Highway) and a railway line in the south. Heavy metal concentrations in roadside soils result from vehicle exhausts and the corroding metal parts of vehicles. Due to the difficulty of removing heavy metals from the soil, a significant pollution problem arises and this pollution also affects the water resources by means of rain. Although there are several industries, the highway located near the lake is the most important pollutant source for Sapanca Basin. Therefore, this study evaluated heavy metal concentrations, the chemical fractions of the metals and ecological risks (by using $\mathrm{C}_{\mathrm{f}}, \mathrm{RAC}$ and PERI) in the soil samples collected seasonally between 2015 and 2017 in Sapanca Lake Basin. Al and Fe were determined at very high amounts in all stations and the relationship between mean concentrations of other metals was determined to be $\mathrm{Zn}>\mathrm{Ba}>\mathrm{As}>\mathrm{Ni}>\mathrm{Cr}>\mathrm{Pb}>\mathrm{Cu}>\mathrm{Co}>\mathrm{Cd}$. However, $\mathrm{Zn}, \mathrm{Ba}, \mathrm{As}, \mathrm{Ni}, \mathrm{Cr}, \mathrm{Pb}, \mathrm{Cu}, \mathrm{Co}$ and $\mathrm{Cd}$ mean concentrations were determined as $87.63 \mathrm{mg} / \mathrm{kg}, \mathrm{Ba} 86.87 \mathrm{mg} / \mathrm{kg}, 80.40 \mathrm{mg} / \mathrm{kg}, 58.62 \mathrm{mg} / \mathrm{kg}$, $50.42 \mathrm{mg} / \mathrm{kg}, 41.90 \mathrm{mg} / \mathrm{kg}, 38.16 \mathrm{mg} / \mathrm{kg}, 13.98 \mathrm{mg} / \mathrm{kg}, 2.89 \mathrm{mg} / \mathrm{kg}$ respectively. Al, Fe, Co, Cr, $\mathrm{Cu}, \mathrm{Ni}$ and $\mathrm{Zn}$ are mainly found in residual fractions in soil. According to the environmental risk assessment on the basis of soil stations, the $7^{\text {th }}$ station has the highest $\mathrm{GC}_{\mathrm{f}}$ value, which means that the soil sample presents the highest environmental risk according to the contamination factors. On the other hand, Cd has serious potential ecological risk and As has considerable potential ecological risk in all stations.
\end{abstract}

Keywords: heavy metal, ecological risk, Sapanca Lake, soil pollution, sequential extraction

*e-mail: aates@sakarya.edu.tr 


\section{Introduction}

Heavy metal pollution is at the top of the list of causes and other chemical pollutants that can arise from various sources, being resistant to environmental conditions, and can easily enter the food chain and accumulate in increasing concentrations in living organisms $[1,2]$. Heavy metals have high environmental durability, and heavy metal can enter soil through natural sources and anthropogenic sources such as: weathering of rocks, precipitation, traffic, industry and agricultural activities [3]. Heavy metals, which are trace elements, are identified as metal or metalloids, having a specific density greater than $5 \mathrm{gr} / \mathrm{cm}^{3}$ [4]. Long-term accumulation of heavy metals in the soil threatens human health through the food chain and ecosystem. So, heavy metals have become the most important pollutants in soil all over the world [5].

Soil pollution is a major environmental issue worldwide and has an important role for many different pollutants and particularly, the largest receiving environment exposed to all metal pollution in the ecosystem [1]. Heavy metal accumulation can reduce the quality of agricultural products, reduce product yield, impair soil quality and directly affect the physicochemical properties of soil. Contrary to the majority of organic pollutants that have lost toxicity due to biodegradation, they can cause long-term toxic effects since metals are not degraded [6, 7]. Also, depending on the physicochemical characteristics of the soil, such as ORP, $\mathrm{pH}$, conductivity, soil texture, organic matter and organic carbon, heavy metals may enter from the soil to the aquatic ecosystem and contaminate the drinking water system [8,9]. Heavy metal pollution in soil has become an important problem worldwide and researchers have focused on this pollution [10-13].

Heavy metals accumulate in different geochemical fractions (organic-associated, exchangable, carbonateassociated, $\mathrm{Fe}, \mathrm{Mn}$ oxide-associated and phyllosilicate minerals) in soils or sediments. In the soil or sediment, the bioavailable concentrations of trace elements are analyzed by using sequential extraction procedures that are commonly used to examine the mobility of trace elements in the soil [11, 14-17]. In the soil analyzed by this method; information on total concentrations, mobility and toxicity of heavy metals can be obtained. For this purpose, a standard consecutive extraction method has been prepared and used by the European Union Reference Commission (BCR - the European Community Bureau of Reference) in order to compare the results determined by different consecutive extraction methods in a healthy way $[1,18]$. In the BCR method, whose new name is SM \& $T$ (The Standard Measurement and Testing Program), heavy metal fractions are listed as follows: can be changed and evaluated in three steps depending on carbonates, reducible (depending on $\mathrm{Fe}$ - and Mn-oxides), and oxidizable (depending on organic matter and sulfides).
As the fourth step, the residual part contains metals bound to soluble minerals in strong acid mixtures.

This extraction method has been used to estimate the fractionation and total concentration of heavy metals in soils in numerous studies. For example, in the study by Zemberyova et al. (2006), the modified BCR sequential extraction method was used for heavy metal determination in different Slovakian soils. Cd, $\mathrm{Cr}, \mathrm{Cu}, \mathrm{Ni}, \mathrm{Pb}$ and $\mathrm{Zn}$ results have been reported to be satisfactory for the study [19]. Nannoni et al. (2011) studied the fractions of $\mathrm{As}, \mathrm{Cd}, \mathrm{Cu}, \mathrm{Pb}, \mathrm{Sb}$ and $\mathrm{Zn}$ in northern Kosova mining areas. It has been reported that the pollutant levels are high in general and local areas, while the values of $\mathrm{Pb}, \mathrm{Zn}, \mathrm{Cd}$ and $\mathrm{Sb}$ increase as the mining areas are approached. It has been reported that lead is generally present in the mobile fraction (the sum of the first three digits of the BCR method), the $\mathrm{Cd}$ element is more extrudable and reducible, and the As, $\mathrm{Cu}, \mathrm{Sb}$ and $\mathrm{Zn}$ elements are in the residual fraction. The order of mobility of heavy metals is reported as $\mathrm{Cd}>\mathrm{Zn}>\mathrm{Pb}>\mathrm{Sb}>\mathrm{As}>\mathrm{Cu}[20]$.

On the other hand, the ecological risks of heavy metals in soil can be examined using many different pollutant indexes [5, 9, 21-25]. In these studies, the ecological risks of heavy metals were assessed by total concentration of the metals in soil or sediment. Total concentration of the metals can't provide effective ecological risk assessment in soil or sediment $[8,11$, $25,26]$. So, heavy metal concentrations in soil should be determined according to the metal fractions. Determining concentrations by fractionation into fractions of heavy metals allows for a more detailed interpretation of possible sources of contaminants of heavy metals and a more reliable risk assessment.

Sapanca Lake is an important drinking water source located alongside the D-100 highway in the north and alongside E-80 (TEM Anatolian Highway) and a railway line in the south. Heavy metal concentrations in roadside soils result from vehicle exhausts and the corroding metal parts of vehicles. Due to the difficulty of removing heavy metals from the soil, a significant pollution problem arises and this pollution also affects the water resources by means of rain. Although there are several industries, the highway located near the lake is the most important pollutant source for Sapanca Basin. The aim of this study is to detect heavy metal pollution in the basins of Lake Sapanca in Turkey - an important source of drinking water. It also examines the degree of heavy metal pollution in the soil by ecological risk assessment using different methods.

\section{Material and Methods}

\section{Study Area and Sampling Strategy}

Sapanca Lake is a freshwater lake located in the Marmara region at a height of $30 \mathrm{~m}$ above sea level 

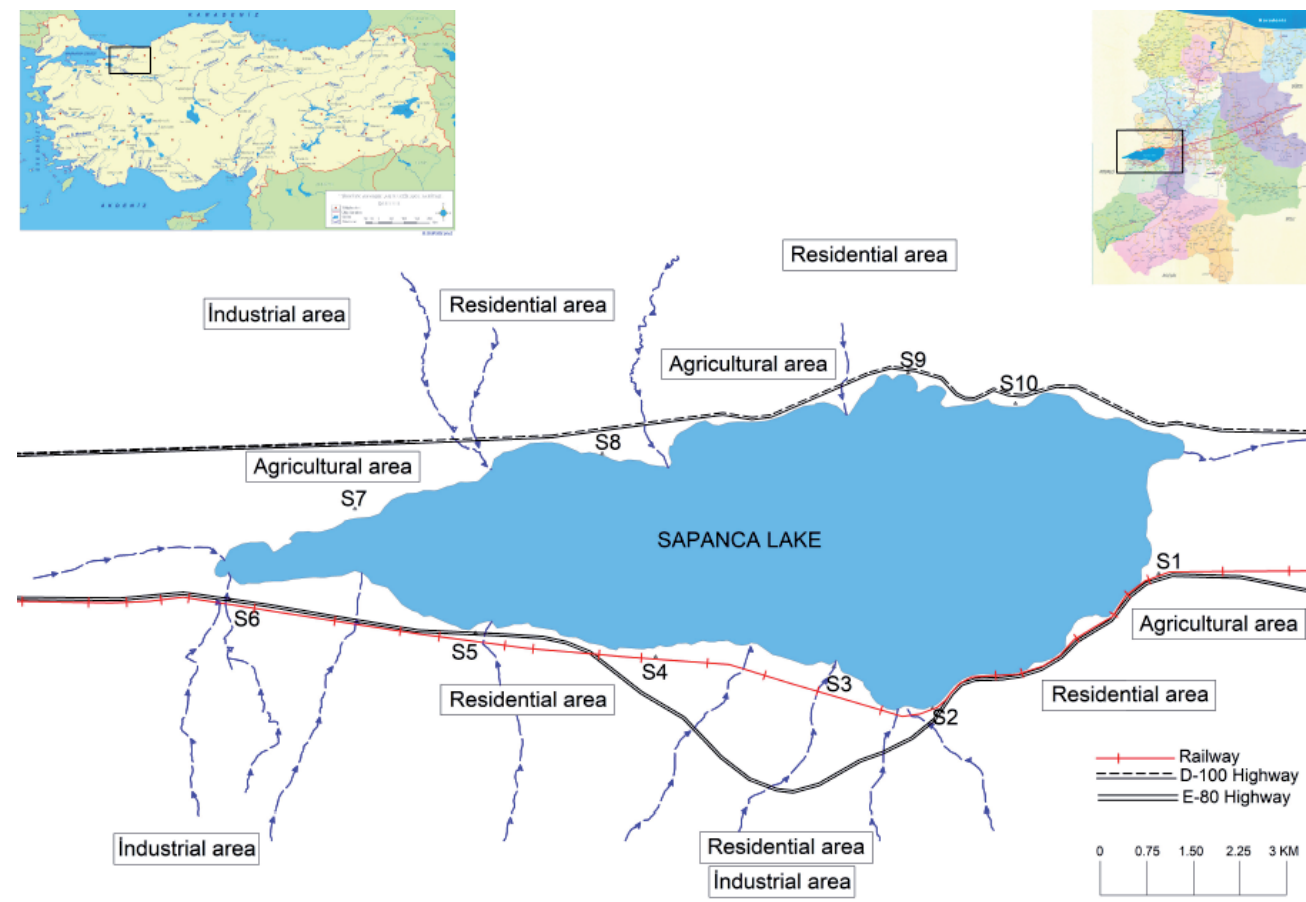

Fig. 1. Map of soil samples in Sapanca Lake basin.

in a tectonic pit. It extends parallel to Iznik Lake and reaches up to Adapazari Plain as a continuation of Izmit Bay (Fig. 1). It is known that underground waters also feed the lake. Fruit, vegetable and cereal production are important agricultural activities to the south and southwest of the lake. The use of pesticides and chemical fertilizers is widespread in the region in order to protect agricultural products against disease and harm, and to increase productivity. Sapanca Lake is used both as a drinking water source and as process water for factories and facilities. The D-100 highway is located in the north of the lake, TEM Anatolian Highway and railway are located in the south. As a result of this heavy traffic, there are gas stations on the coast of the lake [27].

70 soil samples were taken from $0-40 \mathrm{~cm}$ depth from 10 points around the lake to represent the Sapanca Basin in Fig. 1. Samples were collected from soils according to the TS (Turkish Standards Institute) Standard "Soil Quality-Surface Soil Sampling, Sampling and Storage Rules of Samples" numbered 9923 and dated March 1992. Soil samples were taken with a removable soil tube sampler, transferred to plastic bags and then brought to the laboratory in safety.

\section{Analysis Methods}

Firstly, the glass and laboratory materials were washed with detergent and rinsed and then allowed to stand overnight in a $10 \% \mathrm{HNO}_{3}$ solution. The materials were removed from the acid solution and passed through deionized water and then dried at $105^{\circ} \mathrm{C}$. The soil samples were dried at $105^{\circ} \mathrm{C}$ until hard weighing was obtained, and samples were ground in porcelain mortar and then sieved with 100 mesh and 230 mesh sieves. Organic matter, organic carbon, conductivity, $\mathrm{pH}$, oxidation-reduction potential (ORP), and salinity parameters were determined according to standard methods.

The soil was measured with a YSI Professional Plus Multiparameter in suspension $(\mathrm{pH})$, salinity, conductivity, oxidation-reduction potential (ORP), and 1:5 (soil:water ratio) suspension. 5 grams of soil sample was weighed, $25 \mathrm{~mL}$ of purified water was added, and a shaker was mixed for 1 hour. Measurements were made on the liquid part, which was clear on the top of the suspension.

\section{BCR Sequential Extraction Method}

After collecting the soil samples, heavy metal concentrations were identified in accordance with the methodology presented by Tessier et al. (1979) and the four-step successive extraction method (current name) (BCR - the European Community Bureau of Reference) developed by the commission, which is the European Standards, Measurements and Testing Program of the European Commission [28]. The four-step BCR sequential extraction procedure is summarized below.

$1 \mathrm{~g}$ soil samples were placed into $50 \mathrm{~mL}$ PE tubes and then the procedure was applied as shown in Table 1. After each fraction process, the supernatant liquid was decanted into a $50 \mathrm{~mL} \mathrm{PE}$ tube and stored at $4^{\circ} \mathrm{C}$ prior to analysis. Only the supernatant liquid in the residual fraction was completed to $50 \mathrm{~mL}$ with nitric acid and stored at $4^{\circ} \mathrm{C}$. The determinations of levels of $\mathrm{Al}$, As, $\mathrm{Ba}, \mathrm{Cd}, \mathrm{Co}, \mathrm{Cr}, \mathrm{Cu}, \mathrm{Fe}, \mathrm{Ni}, \mathrm{Pb}$ and $\mathrm{Zn}$ in the extracts were performed by ICP-OES. 
Table 1. BCR sequential extraction procedure.

\begin{tabular}{|c|c|c|c|}
\hline Fractions & Fraction in Soil & Extract material & Shaking time and temperature \\
\hline $\mathrm{F}_{1}$ & Exchangeable metals & $40 \mathrm{~mL} 0.11 \mathrm{M} \mathrm{CH}_{3} \mathrm{COOH}$ & $200 \mathrm{rpm}$ and 16 hour at laboratory temperature \\
\hline $\mathrm{F}_{2}$ & $\begin{array}{l}\text { Metals bound to iron and manganese } \\
\text { oxides (reducible) }\end{array}$ & $\begin{array}{c}40 \mathrm{~mL} 0.5 \mathrm{M} \mathrm{HONH}_{2} \cdot \mathrm{HCl} \\
(\mathrm{pH} 1,5)\end{array}$ & $200 \mathrm{rpm}$ and 16 hour at laboratory temperature \\
\hline $\mathrm{F}_{3}$ & $\begin{array}{l}\text { Metals bound to organic matter and } \\
\text { sulfides (oxidizable) }\end{array}$ & $\begin{array}{c}10 \mathrm{~mL} 8.8 \mathrm{M} \mathrm{H}_{2} \mathrm{O}_{2}(\mathrm{pH} 2) \\
10 \mathrm{~mL}^{\circ} .8 \mathrm{M} \mathrm{H}_{2} \mathrm{O}_{2}(\mathrm{pH} 2) \\
50 \mathrm{~mL} 1 \mathrm{M} \mathrm{NH}_{4} \mathrm{OAc}_{(\mathrm{pH} 2)}\end{array}$ & $\begin{array}{c}200 \mathrm{rpm} \text { and } 1 \text { hour at laboratory temperature } \\
1 \text { hour at } 85^{\circ} \mathrm{C} \text { (is only heated) } \\
1 \text { hour at laboratory temperature }\end{array}$ \\
\hline $\mathrm{F}_{4}(\mathrm{R})$ & Residual & $15 \mathrm{~mL}$ aqua regia & $\begin{array}{l}\text { It is heated to the dryness and constant volume } \\
\text { is completed }\end{array}$ \\
\hline
\end{tabular}

However, the reagents and chemicals were all at analytical grade. Reagent blanks, calibration with standard solutions, triplicate samples and the standard reference materials (BCR-701) were performed to guarantee quality assurance and quality control. The recovery ratios were determined as over $95 \%$ for each heavy metal (Cd 98\%, Cr 95\%, Cu 95\%, Ni 97\%, Pb 99\%, Zn 101\%).

\section{Results and Discussion}

\section{Soil Properties}

Physicochemical characteristics of soil affect heavy metal accumulation and mobility of the metals in the soil. Depending on ORP, $\mathrm{pH}$, conductivity, soil texture and organic matter, heavy metals can be transferred from the soil to the aquatic system and contaminate the water sources. Especially $\mathrm{pH}$, ORP and organic matter play an important role in the mobility of heavy metals in soils or sediments. As has been presented in Table 2, $\mathrm{pH}$ and conductivity values range from 6.49 to 8.63 , and $150.10 \mu \mathrm{S} / \mathrm{cm}$ to $625.40 \mu \mathrm{S} / \mathrm{cm}$. Organic matter content of Sapanca Lake basin is very low. The rate of maximum organic matter is $14.39 \%$ and the rate of maximum organic carbon is $8.35 \%$. Soils primarily consist of sand and silt in all stations (except the $4^{\text {th }}$ and $7^{\text {th }}$ stations), as shown in Fig. 2. The highest silt (52\%) content is determined in the $8^{\text {th }}$ station and the highest sand content is $65 \%$ in the $9^{\text {th }}$ station and $61 \%$ in the $2^{\text {nd }}$ station, respectively. Soil samples have gravel texture except the $8^{\text {th }}$ and $9^{\text {th }}$ stations. Most anthropogenic contaminants are associated with the clay and silt fractions [29]. Generally, the silt content has a high percentage in all soil samples in Sapanca Lake basin.

On the other hand, soils rich in clay and organic matter hold heavy metals and form tough soluble compounds. Keeping heavy metals in the soil varies depending on the amount of organic matter in the soil and the type of clay minerals. Movement of heavy metals into the mobile is of great importance for both plants and bottom waters. Heavy metals that accumulate in soils can be washed from the soil depending on the $\mathrm{pH}$ value in shallow, coarse (sandy) and organic matter content in low soils and mixed with groundwater.

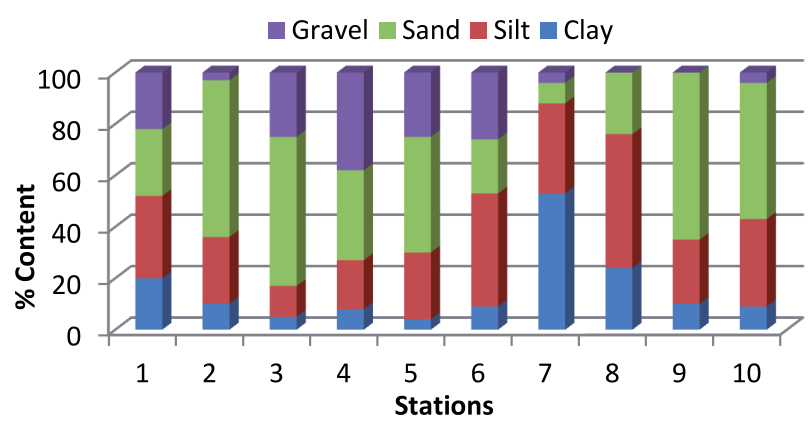

Fig. 2. Soil face distributions in Sapanca Lake.

Table 2. Basic statistics of physico-chemical parameters.

\begin{tabular}{|c|c|c|c|c|c|c|}
\hline & $\begin{array}{c}\mathrm{C} \\
(\mu \mathrm{S} / \mathrm{cm})\end{array}$ & $\begin{array}{c}\mathrm{SAL} \\
(\mathrm{ppt})\end{array}$ & $\mathrm{pH}$ & $\begin{array}{c}\text { ORP } \\
(\mathrm{mV})\end{array}$ & OM \% & OC \% \\
\hline Min & 150.10 & 0.01 & 6.49 & 111.40 & 1.94 & 1.12 \\
\hline Max & 625.40 & 0.34 & 8.63 & 352.50 & 14.39 & 8.35 \\
\hline Median & 284 & 0.14 & 7.91 & 243.40 & 6.15 & 3.57 \\
\hline Mean & 302.17 & 0.13 & 7.87 & 245.24 & 6.50 & 3.77 \\
\hline Std & 109.60 & 0.07 & 0.45 & 49.38 & 2.81 & 1.63 \\
\hline
\end{tabular}

C: conductivity, Sal: salinity, ORP: oxidation-reduction potential, OM: organic matter, OC: organic carbon 
Table 3. Total heavy metals concentrations $(\mathrm{mg} / \mathrm{kg})$.

\begin{tabular}{|c|c|c|c|c|c|c|c|c|c|c|c|}
\hline \multirow{2}{*}{ Stations } & \multicolumn{9}{|c|}{$\mathrm{AM}$} \\
\cline { 2 - 14 } & $\mathrm{Al}$ & $\mathrm{As}$ & $\mathrm{Ba}$ & $\mathrm{Cd}$ & $\mathrm{Co}$ & $\mathrm{Cr}$ & $\mathrm{Cu}$ & $\mathrm{Fe}$ & $\mathrm{Ni}$ & $\mathrm{Pb}$ & $\mathrm{Zn}$ \\
\hline 1 & 112715.35 & 84.88 & 119.29 & 3.05 & 13.89 & 55.22 & 32.22 & 379892.90 & 70.76 & 37.22 & 68.53 \\
\hline 2 & 16211.32 & 78.57 & 93.94 & 2.68 & 14.26 & 42.49 & 32.11 & 37230.19 & 64.14 & 36.21 & 69.29 \\
\hline 3 & 13238.32 & 77.35 & 40.20 & 2.47 & 13.93 & 44.57 & 38.57 & 37632.45 & 63.87 & 39.07 & 79.14 \\
\hline 4 & 12355.89 & 81.01 & 48.32 & 2.61 & 10.65 & 35.62 & 34.99 & 32308.68 & 43.85 & 37.21 & 70.45 \\
\hline 5 & 11163.81 & 76.04 & 61.25 & 2.48 & 10.74 & 45.36 & 42.33 & 30323.50 & 46.96 & 47.30 & 147.77 \\
\hline 6 & 16190.98 & 73.75 & 46.68 & 2.64 & 11.70 & 62.45 & 34.46 & 35518.95 & 52.60 & 44.49 & 84.65 \\
\hline 7 & 26100.26 & 79.96 & 125.88 & 3.63 & 23.66 & 50.76 & 41.74 & 44639.03 & 57.85 & 60.85 & 74.45 \\
\hline 8 & 19303.12 & 81.85 & 121.91 & 2.76 & 12.88 & 60.61 & 39.55 & 36213.80 & 63.08 & 35.28 & 87.01 \\
\hline 9 & 19121.90 & 84.49 & 98.11 & 3.01 & 14.04 & 54.28 & 44.57 & 36402.71 & 57.12 & 40.46 & 102.58 \\
\hline 10 & 15252.07 & 83.19 & 117.31 & 3.17 & 13.02 & 47.06 & 38.59 & 31732.82 & 61.72 & 38.67 & 92.46 \\
\hline Min & 11163.81 & 73.75 & 40.20 & 2.47 & 10.65 & 35.62 & 32.11 & 30323.50 & 43.85 & 35.28 & 68.53 \\
\hline Max & 112715.35 & 84.88 & 125.88 & 3.63 & 23.66 & 62.45 & 44.57 & 379892.90 & 70.76 & 60.85 & 147.77 \\
\hline Mean & 26165.30 & 80.11 & 87.29 & 2.85 & 13.88 & 49.84 & 37.91 & 70189.50 & 58.20 & 41.68 & 87.63 \\
\hline
\end{tabular}

\section{Heavy Metal Levels in Soil}

The statistical heavy metal results of samples are presented in Table 3. Soil samples were digested by using the aforementioned BCR sequential extraction method, and heavy metal concentrations were determined in ICP-OES. As presented in Table 3, total heavy metal concentrations can be given on the basis of the stations and the concentrations of $\mathrm{Al}$ and $\mathrm{Fe}$ are far greater than the other metals. Consequently, the soil of Sapanca Lake basin is very rich in these two elements, which originated from crustal [30]. The heavy metal concentrations are $\mathrm{Fe}>\mathrm{Al}>\mathrm{Zn}>\mathrm{Ba}>\mathrm{As}>\mathrm{Ni}>\mathrm{Cr}>\mathrm{Pb}>$ $\mathrm{Cu}>\mathrm{Co}>\mathrm{Cd}$. The total heavy metal concentrations are determined as: As 73.75-84.88 $\mathrm{mg} / \mathrm{kg}, \quad \mathrm{Ba}$ $46.20-125.88 \mathrm{mg} / \mathrm{kg}, \quad$ Cd $2.47-3.63 \mathrm{mg} / \mathrm{kg}, \quad$ Co $10.65-23.66 \mathrm{mg} / \mathrm{kg}, \quad \mathrm{Cr} \quad 35.62-62.45 \mathrm{mg} / \mathrm{kg}, \quad \mathrm{Cu}$ $32.11-44.57 \mathrm{mg} / \mathrm{kg}, \quad \mathrm{Ni} \quad 43.85-70.76 \mathrm{mg} / \mathrm{kg}, \quad \mathrm{Pb}$ $35.28-60.85 \mathrm{mg} / \mathrm{kg}$ and $\mathrm{Zn} 68.53-147.77 \mathrm{mg} / \mathrm{kg}$. The maximum values of heavy metal were observed at the $7^{\text {th }}$ station, which is located near agricultural and industrial areas. However, the maximum values of As and $\mathrm{Ni}$ are determined at the $1^{\text {st }}$ station while $\mathrm{Cr}, \mathrm{Cu}$ and $\mathrm{Zn}$ values are determined at the $6^{\text {th }}, 9^{\text {th }}$ and $5^{\text {th }}$ stations, respectively.

Fig. 3 shows a histogram of heavy metals in Sapanca Lake basin. The results show that $\mathrm{Al}$ and Fe are dominantly found in the residual fraction and these elements, which originated from earth's crust, are not associated with the exchangeable fraction in the soil samples. The dominant fraction of $\mathrm{Cr}, \mathrm{Ni}$ and $\mathrm{Zn}$ is the residual fraction, which accounts for $81.5 \%, 61.36 \%$ and $53.45 \%$ of the total concentration, respectively. It is likely that the heavy metals associated with the residual fractions are involved in the aluminosilicate minerals and so are unlikely to be released into pore-waters through dissociation [3].

The distribution pattern of $\mathrm{Co}$ is as follows: exchangeable fraction $(11.19 \%)<$ oxidizable fraction $(14.29 \%)<$ reducible fraction $(32.99 \%)<$ residual fraction $(41.51 \%)$. So, the residual fraction is the main fraction for $\mathrm{Co}$. A noticeable amount of $\mathrm{Cd}$ is observed in the residual fraction (37.94\%) and the other fractions decrease in the order as follows: reducible fraction $(22.77 \%)>$ oxidizable fraction $21.86 \%>$ residual fraction $17.41 \%$. The levels of $\mathrm{Cu}$ in soils are mainly found in the residual fraction and the percentage of the fractions are as follows: $37.94 \%$ residual, $27.55 \%$ reducible, $15.62 \%$ oxidizable and $7.13 \%$ exchangeable fraction. $\mathrm{As}, \mathrm{Ba}$ and $\mathrm{Pb}$ are distributed in all fractions of the soil, but the dominant fractions are determined in the oxidizable (33.52\% for As) and reducible fraction (44.72\% and $39.36 \%$ for $\mathrm{Ba}$ and $\mathrm{Pb}$ ).

Generally, heavy metals are mainly observed in the residual fraction at all stations (as shown in Fig. 3). Al and $\mathrm{Fe}$ elements are dominantly found in the oxidizable fraction $(43.13 \%$ and $46.33 \%)$ in the $1^{\text {st }}$ station, and $\mathrm{Cr}$ and $\mathrm{Ni}$ are mostly observed in the oxidizable fraction $(21.96 \%$ and $24.16 \%)$ in the $7^{\text {th }}$ station. For Co, the main fraction is the reducible fraction in the $7^{\text {th }}$ station.

\section{Correlation Analysis for Heavy Metals and Physicochemical Characteristics}

Table 4 shows the relationship between heavy metals in the soil of Sapanca Lake basin. A significant and positive correlation is observed between $\mathrm{Al}$ and $\mathrm{Fe}\left(\mathrm{r}^{2}=0.996\right)$, As and $\mathrm{Cd}\left(\mathrm{r}^{2}=0.925\right)$ and $\mathrm{Ni}$ and $\mathrm{Cr}$ 

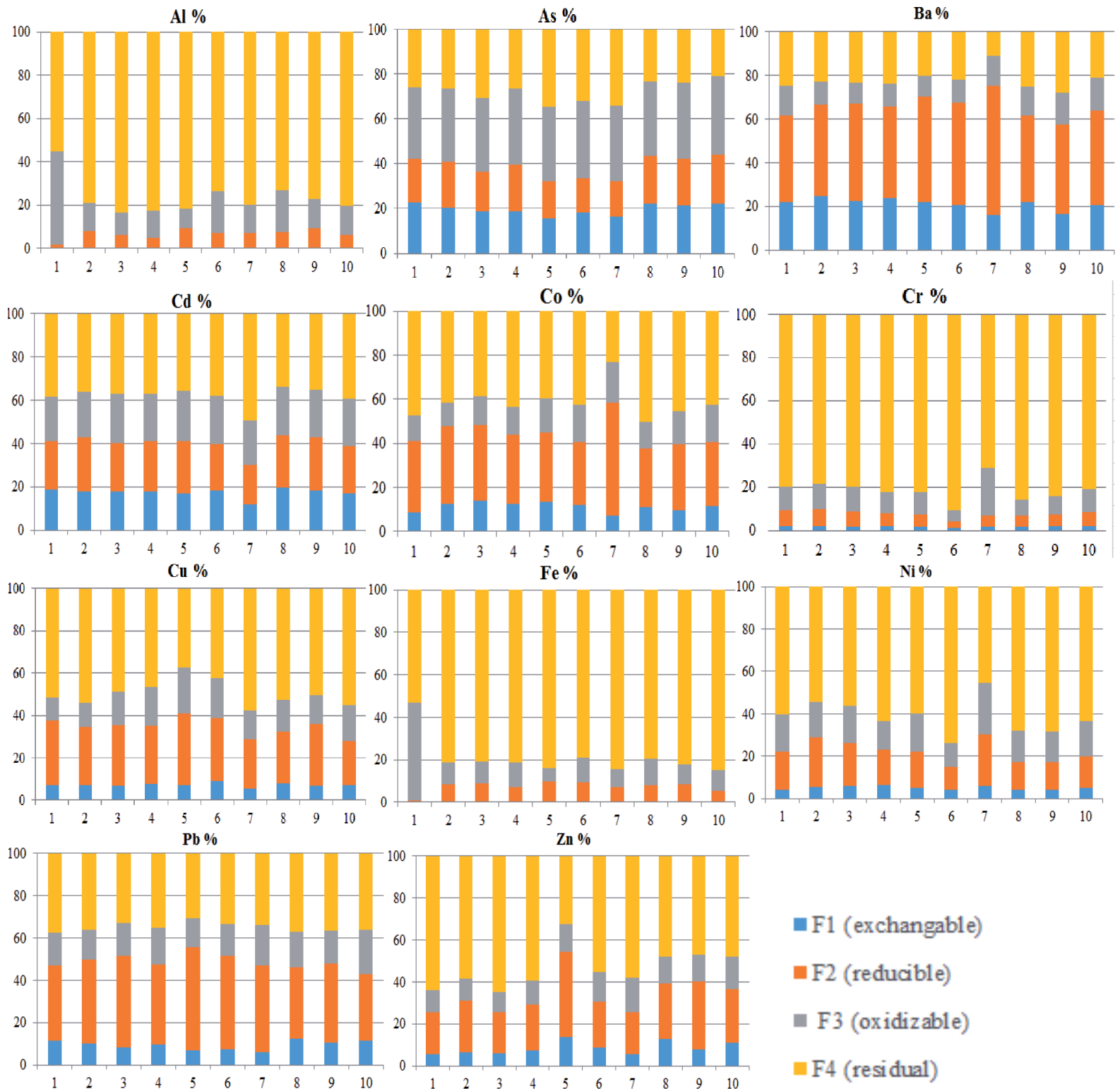

Fig. 3. Fractionation distribution characteristics of trace elements.

$\left(r^{2}=0.903\right)$ (Table 4). This state means that these heavy metals may have originated from the same pollutant source and that these metals have some similar properties. There is no correlation between $\mathrm{Ba}$ and the other metals, which indicates that Ba can originate from various pollutant sources. The correlations (in which $\mathrm{r}^{2}$ between these metals is higher than 0.50) among $\mathrm{Cd}$, $\mathrm{Co}, \mathrm{Cu}$ and $\mathrm{Pb}$ are significant. A positive correlation is observed between $\mathrm{As}$ and $\mathrm{Co}, \mathrm{Cr}, \mathrm{Cu}, \mathrm{Ni}$ and $\mathrm{Pb}$. On the other hand, a positive correlation between $\mathrm{pH}$, ORP and SAL is observed. There is a positive correlation among ORP, $\mathrm{pH}$, As and $\mathrm{Cd}$, and $\mathrm{Cr}-\mathrm{ORP}$ correlation is significant.

\section{Evaluating Soil Heavy Metal Pollution}

In order to evaluate heavy metal pollution in Sapanca Lake Basin, we performed three pollution indexes: the contamination factors $\left(\mathrm{C}_{\mathrm{f}}\right)$ of metals, risk assessment code (RAC) and potential ecological risk index method (PERI).

\section{Contamination Factor $\left(\mathrm{C}_{\mathrm{f}}\right)$}

The calculation of contamination factor of heavy metals is an important parameter that identifies the degree of risk of heavy metals to the environment in relation to its retention time [3]. The individual contamination factor $\left(\mathrm{C}_{\mathrm{f}}\right)$ for the 11 metals was calculated according to Fernandes (1997) [31]. $\mathrm{C}_{\mathrm{f}}$ is calculated by dividing the sum of heavy metal concentrations in the mobile fraction (exchangeable, acid-reducible and oxidizable-organic forms) by the residual fraction [3]. The global contamination factor $\left(\mathrm{GC}_{\mathrm{f}}\right)$ was determined as the sum of the $\mathrm{C}_{\mathrm{f}}$ values [32]. 


\begin{tabular}{|c|c|c|c|c|c|c|c|c|c|c|c|c|c|c|c|c|c|}
\hline 8 & & & & & & & & & & & & & & & & ¿̊. & - \\
\hline$\Sigma$ & & & & & & & & & & & & & & & & - & : 8 \\
\hline งี & & & & & & & & & & & & & & & - & $\infty$ & $\underset{\infty}{\infty}$ \\
\hline $\overrightarrow{2}$ & & & & & & & & & & & & & & - & $\frac{*}{*} \frac{n}{7}$ & $\stackrel{*}{\underset{\Im}{\Im}}$ & $\frac{\mathcal{Z}}{\underset{Z}{*}}$ \\
\hline z z & & & & & & & & & & & & & - & : & 可 & ô & 龵 \\
\hline i & & & & & & & & & & & & - & $\tilde{\varepsilon}$ & సे & : & $\cong$ & 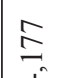 \\
\hline$\tilde{J}$ & & & & & & & & & & & - & 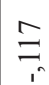 & $\frac{\partial}{\lambda}$ & $\begin{array}{l}* \\
6 \\
6 \\
6\end{array}$ & $\frac{*_{0}^{\prime}}{8}$ & 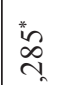 & $\begin{array}{l}1 \\
2 \\
0 \\
\sim n\end{array}$ \\
\hline U & & & & & & & & & & - & సิ & fo & $\stackrel{*}{*}$ & $\stackrel{*}{\stackrel{*}{*}}$ & $\stackrel{\circ}{\circ}$ & $\widehat{\Xi}$ & $\widehat{\cong}$ \\
\hline 8 & & & & & & & & & - & 跣 & $\stackrel{*}{\stackrel{*}{f}}$ & in & 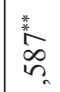 & 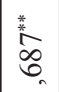 & \&̊ & $\begin{array}{l}* \\
\text { D. } \\
\text { D. }\end{array}$ & 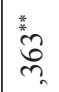 \\
\hline$\tilde{J}$ & & & & & & & & - & $\begin{array}{l}* \\
6 \\
6 \\
6\end{array}$ & 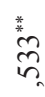 & $\frac{{ }^{*}}{\stackrel{*}{n}}$ & $\underset{0}{\infty}$ & 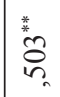 & $\begin{array}{l}* \\
\hat{2} \\
6 \\
0\end{array}$ & $\vec{b}$ & 8 & $\hat{8}$ \\
\hline$\ddot{\oplus ే}$ & & & & & & & - & 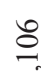 & $\begin{array}{l}\omega_{n}^{*} \\
n \\
m\end{array}$ & 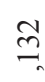 & $\bar{\square}$ & $\Xi$ & 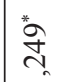 & $\stackrel{m}{0}$ & $\stackrel{?}{8}$ & $\frac{*}{\stackrel{3}{m}}$ & $\frac{*}{2}$ \\
\hline \& & & & & & & - & 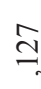 & $\stackrel{*}{i}$ & $\begin{array}{l}* \\
0 \\
0 \\
n\end{array}$ & $\begin{array}{l}n_{n}^{2} \\
\tilde{n}\end{array}$ & $\stackrel{*}{*} \underset{\sim}{\tilde{F}}$ & ồ & 金 & 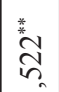 & $\stackrel{\varrho}{=}$ & 㕝 & 吉 \\
\hline « & & & & & - & $\begin{array}{l}\infty \\
\stackrel{\infty}{0} \\
i\end{array}$ & 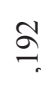 & $\hat{o}_{i}$ & fo & $\mathbb{S}_{i}$ & $\vec{m}$ & హ. & $\underset{i}{\sigma_{i}}$ & $\stackrel{2}{\stackrel{2}{c}}$ & $\mathbb{O}_{i}^{\infty}$ & $\frac{8}{i n}$ & $\stackrel{8}{?}$ \\
\hline 气ิ & & & & - & §̊. & $\stackrel{*}{\stackrel{*}{*}}$ & $\tilde{g}_{0}$ & 类 & ले & 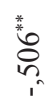 & $\stackrel{\infty}{i}$ & ठे. & 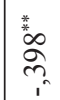 & 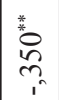 & $\begin{array}{l}0 \\
\stackrel{2}{0} \\
i\end{array}$ & $\stackrel{\infty}{\simeq}$ & $\cong$ \\
\hline 蛋 & & & - & 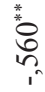 & $\stackrel{8}{\circ}$ & $\begin{array}{l}{ }^{*} \\
\text { in } \\
\text { n. }\end{array}$ & $\frac{5}{0}$ & مِ & 䓦 & 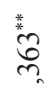 & $\stackrel{2}{\exists}$ & $\AA_{i}$ & 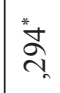 & $\stackrel{\infty}{\stackrel{\sim}{~}}$ & $\hat{0}_{i}^{\infty}$ & $\stackrel{8}{\because}$ & $\because$ \\
\hline 岕 & & - & $\stackrel{\text { 恙 }}{\stackrel{2}{n}}$ & 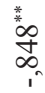 & $\begin{array}{l}\infty \\
\stackrel{\infty}{0}\end{array}$ & $\frac{*}{6}$ & $\overline{8}$ & 苦 & $\begin{array}{l}* \\
\hat{n} \\
n\end{array}$ & $\begin{array}{l}v_{0}^{*} \\
\sigma \\
\sigma\end{array}$ & ठे. & $\underset{i^{\prime}}{\mathbb{Z}}$ & $\begin{array}{l}* \\
\infty \\
\infty \\
\infty \\
n\end{array}$ & $\begin{array}{l}\hat{*} \\
\stackrel{\infty}{\infty} \\
\end{array}$ & $\vec{\delta}$ & $\tilde{\delta}_{0}$ & $\overbrace{0}$ \\
\hline U & - & 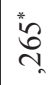 & $\stackrel{2}{0}$ & in & $\stackrel{\circ}{0}$ & $\stackrel{\circ}{\stackrel{\sim}{N}}$ & $\mathscr{\delta}_{i}$ & $\stackrel{\infty}{\longrightarrow}$ & $\stackrel{\circ}{n}$ & $\bar{m}$ & $\hat{0}$ & $\hat{\theta}_{i}$ & ర్ర & $\begin{array}{l}i n \\
\tilde{n} \\
\tilde{n}\end{array}$ & $\hat{8}_{i}$ & $\stackrel{0}{0}$ & క̊ \\
\hline & U & $\vec{U}$ & 胥 & 气ै & « & $\frac{n}{4}$ & $\tilde{\oplus}$ & $\bar{J}$ & 8 & U & 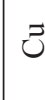 & D. & $\bar{z}$ & $\overrightarrow{2}$ & งี & $\sum_{0}$ & ठ \\
\hline
\end{tabular}


Table 5. Contamination factor values of heavy metals in soil.

\begin{tabular}{|c|c|c|c|c|c|c|c|c|c|c|c|c|}
\hline \multirow{2}{*}{ Stations } & \multicolumn{11}{|c|}{$\mathrm{C}_{\mathrm{f}}$} & \multirow{2}{*}{$\mathrm{GC}_{\mathrm{f}}$} \\
\hline & $\mathrm{Al}$ & As & $\mathrm{Ba}$ & $\mathrm{Cd}$ & Co & $\mathrm{Cr}$ & $\mathrm{Cu}$ & $\mathrm{Fe}$ & $\mathrm{Ni}$ & $\mathrm{Pb}$ & $\mathrm{Zn}$ & \\
\hline 1 & 0.81 & 2.82 & 3.02 & 1.59 & 1.11 & 0.25 & 0.94 & 0.89 & 0.66 & 1.67 & 0.57 & 14.33 \\
\hline 2 & 0.26 & 2.77 & 3.37 & 1.78 & 1.40 & 0.28 & 0.85 & 0.23 & 0.84 & 1.77 & 0.71 & 14.25 \\
\hline 3 & 0.20 & 2.26 & 3.30 & 1.69 & 1.59 & 0.26 & 1.05 & 0.24 & 0.77 & 2.03 & 0.54 & 13.93 \\
\hline 4 & 0.21 & 2.78 & 3.23 & 1.71 & 1.29 & 0.21 & 1.15 & 0.23 & 0.58 & 1.85 & 0.68 & 13.90 \\
\hline 5 & 0.23 & 1.87 & 3.98 & 1.79 & 1.53 & 0.21 & 1.65 & 0.19 & 0.67 & 2.27 & 2.09 & 16.49 \\
\hline 6 & 0.35 & 2.14 & 3.57 & 1.65 & 1.34 & 0.10 & 1.37 & 0.27 & 0.36 & 1.99 & 0.81 & 13.95 \\
\hline 7 & 0.25 & 1.92 & 8.12 & 1.04 & 3.35 & 0.40 & 0.74 & 0.18 & 1.20 & 1.96 & 0.73 & 19.89 \\
\hline 8 & 0.36 & 3.25 & 2.96 & 1.97 & 0.98 & 0.17 & 0.90 & 0.26 & 0.48 & 1.69 & 1.09 & 14.11 \\
\hline 9 & 0.29 & 3.23 & 2.56 & 1.85 & 1.19 & 0.19 & 0.98 & 0.22 & 0.46 & 1.74 & 1.13 & 13.85 \\
\hline 10 & 0.24 & 3.77 & 3.80 & 1.55 & 1.34 & 0.24 & 0.82 & 0.18 & 0.57 & 1.75 & 1.09 & 15.35 \\
\hline Min & 0.20 & 1.87 & 2.56 & 1.04 & 0.98 & 0.10 & 0.74 & 0.18 & 0.36 & 1.67 & 0.54 & 13.85 \\
\hline Max & 0.81 & 3.77 & 8.12 & 1.97 & 3.35 & 0.40 & 1.65 & 0.89 & 1.20 & 2.27 & 2.09 & 19.89 \\
\hline Mean & 0.32 & 2.68 & 3.79 & 1.66 & 1.51 & 0.23 & 1.04 & 0.29 & 0.66 & 1.87 & 0.94 & 15.01 \\
\hline
\end{tabular}

Table 5 shows the calculated individual and global contamination factors of heavy metals in the soil samples at all stations. The $7^{\text {th }}$ station has the highest $\mathrm{GC}_{\mathrm{f}}$ value, which means that this soil sample carries the highest environmental risk. The $\mathrm{GC}_{\mathrm{f}}$ values are identified as $7>5>10>1>2>8>6>3>4>9$. Cr has the lowest $\mathrm{C}_{\mathrm{f}}$ values, ranging from 0.10 to 0.40 , and also $\mathrm{Al}, \mathrm{Fe}$, $\mathrm{Ni}$ and $\mathrm{Zn}$ values ranging from 0.20 to $0.81,0.18$ to $0.89,0.36$ to 2.09 and 0.54 to 2.09 , respectively. Ba has the highest $\mathrm{C}_{\mathrm{f}}$ values, ranging from 2.56 to 8.12 , which mean that $\mathrm{Ba}$ can be removed from Sapanca Lake Basin at a faster rate than the other metals because a higher relative metal retention depending on the lower $\mathrm{C}_{\mathrm{f}}$ values has been observed [32]. According to $\mathrm{C}_{\mathrm{f}}$, the As, Cd, $\mathrm{Co}, \mathrm{Cu}$ and $\mathrm{Pb}$ are released from the $10^{\text {th }}, 8^{\text {th }}, 7^{\text {th }}$ and $5^{\text {th }}$ stations in Sapanca Lake basin, respectively. Generally, the chemical forms of these metals, except for $\mathrm{Ba}$, are all dominated by the residual fractions in this study. On the other hand, the non-residual fraction is more suitable for the investigation of soil-plant systems and this fraction is an important factor that affects the mobility of heavy metals.

\section{Risk Assessment Code (RAC)}

In this method, pollution is calculated by dividing the metal of an exchangeable fraction (step 1) to the total content of the metal in all fractions. RAC is commonly used to examine the availability of the heavy metals in the eco-systems, and the method has an important role as an indicator of environmental health [12, 33]. The interpretation of RAC assessment is 'no risk' ( $\mathrm{RAC}<1)$, 'low risk' (1 10\%), 'medium risk' (11 30\%), 'high risk' (31 50\%) and 'very high risk' RAC $\leq 75 \%)$
[34]. Heavy metals are bound with different strengths to the fractions in the soils or sediments [27]. The calculation of risk assessment code depends on heavy metals, which are weakly bound to the solid fraction. So, the heavy metals cause a major environmental issue to the aquatic system due to bioavailability and toxicity [3]. RAC values of soil samples are presented in Table 6.

As presented in Table 6, the soils have a low risk for $\mathrm{Cr}, \mathrm{Cu}$ and $\mathrm{Ni}$, which has $\mathrm{RAC}$ values of less than $10 \%$, which means that these metals have no remarkable mobility in Sapanca Lake basin. As, Ba and $\mathrm{Cd}$ indicate a medium risk in terms of the availability of the heavy metals in the environment. $\mathrm{Co}, \mathrm{Pb}$ and $\mathrm{Zn}$ mostly indicate a medium risk and this issue can turn into a medium risk at all stations in the near future.

\section{Potential Ecological Risk Index (PERI)}

This method exhaustively regards the potential risk of heavy metals in soil or sediment [9, 35]. PERI was designed to assess the heavy metal content toxicity of trace elements in soil or sediment, the kind of pollutant and the toxicity level of heavy metal pollution. The method can be used for the assessment of soil in different areas and has been mostly preferred for environmental risk assessment [22, 36, 38 ]. The index is calculated as follows:

$$
\begin{gathered}
R I=\sum_{i=1}^{m} E_{r}^{i}=\sum_{i=1}^{m} T_{r}^{i} \frac{C_{s}^{i}}{C_{n}^{i}} \\
E_{r}^{i}=T_{r}^{i} C_{f}^{i}
\end{gathered}
$$


Table 6. RAC values of heavy metals in Sapanca Lake Basin.

\begin{tabular}{|c|c|c|c|c|c|c|c|c|c|}
\hline \multirow{2}{*}{ Stations } & \multicolumn{9}{|c|}{ RAC \% } \\
\hline & As & $\mathrm{Ba}$ & $\mathrm{Cd}$ & Co & $\mathrm{Cr}$ & $\mathrm{Cu}$ & $\mathrm{Ni}$ & $\mathrm{Pb}$ & $\mathrm{Zn}$ \\
\hline 1 & 22.55 & 21.75 & 18.67 & 8.43 & 1.83 & 6.97 & 4.05 & 11.29 & 5.36 \\
\hline 2 & 20.29 & 24.73 & 18.04 & 12.43 & 1.94 & 6.99 & 5.60 & 10.10 & 6.23 \\
\hline 3 & 18.62 & 22.61 & 17.68 & 14.15 & 1.74 & 6.85 & 5.84 & 8.09 & 5.99 \\
\hline 4 & 18.86 & 23.60 & 17.70 & 12.43 & 2.16 & 7.71 & 6.33 & 9.80 & 7.51 \\
\hline 5 & 15.63 & 22.08 & 16.89 & 13.44 & 1.52 & 7.10 & 4.83 & 6.74 & 13.70 \\
\hline 6 & 18.10 & 20.76 & 18.08 & 11.75 & 1.13 & 8.71 & 4.12 & 7.36 & 8.52 \\
\hline 7 & 16.39 & 15.83 & 11.90 & 7.33 & 1.48 & 5.42 & 6.03 & 6.19 & 5.65 \\
\hline 8 & 22.43 & 22.08 & 19.69 & 11.10 & 1.62 & 7.94 & 4.22 & 12.18 & 12.98 \\
\hline 9 & 21.40 & 16.29 & 18.37 & 9.34 & 1.84 & 6.50 & 3.95 & 10.55 & 7.61 \\
\hline 10 & 22.18 & 20.74 & 17.12 & 11.54 & 2.11 & 7.13 & 4.79 & 11.46 & 10.92 \\
\hline Min & 15.63 & 15.83 & 11.90 & 7.33 & 1.13 & 5.42 & 3.95 & 6.19 & 5.36 \\
\hline
\end{tabular}

The RI is the potential ecological risk index for multi metals, $\mathrm{E}_{\mathrm{r}}^{\mathrm{i}}$ is the PERI for a single heavy metal, $\mathrm{C}_{\mathrm{f}}^{\mathrm{i}}$ is pollution coefficient of the metal, and $\mathrm{C}_{\mathrm{s}}^{\mathrm{i}}$ and $\mathrm{C}^{\mathrm{i}}{ }_{\mathrm{n}}$ are the measured and the background values of the metal. Background values were taken from Turekian and Wedepohl (1961) [37]. $\mathrm{T}_{\mathrm{r}}^{\mathrm{i}}$ is the toxic factor of the metal provided by Hakanson (1980) and these values are $10(\mathrm{As}), 30(\mathrm{Cd}), 2(\mathrm{Cr}), 5(\mathrm{Cu}, \mathrm{Ni}, \mathrm{Pb})$ and $1(\mathrm{Zn})$, respectively [35]. $\mathrm{T}^{\mathrm{i}}$ reflects the toxicity level and ecological sensitivity to heavy metal pollution [38].

$\mathrm{E}_{\mathrm{r}}^{\mathrm{i}}$ and $\mathrm{RI}$ can be interpreted as: low $\left(\mathrm{E}_{\mathrm{r}}^{\mathrm{i}}<40\right)$, moderate $\left(40 \leq \mathrm{E}_{\mathrm{r}}^{\mathrm{i}}<80\right)$, considerable $\left(80 \leq \mathrm{E}_{\mathrm{r}}^{\mathrm{i}}<160\right)$, high $\left(160 \leq \mathrm{E}_{\mathrm{r}}^{\mathrm{i}}<320\right)$ and serious $\left(320 \leq \mathrm{E}_{\mathrm{r}}^{\mathrm{i}}\right)$, and low $(\mathrm{RI}<150)$, moderate $(150 \leq \mathrm{RI}<300)$, severe $(300 \leq \mathrm{RI}<600)$ and serious $(600 \leq \mathrm{RI})$.

According to the potential ecological risk index calculation, the results of the heavy metals in the soil are presented in Table 7. The metals with $\mathrm{E}_{\mathrm{r}}$ from the highest to the lowest level are $\mathrm{Cd}>>\mathrm{As}>\mathrm{Pb}>\mathrm{Ni}>\mathrm{Cu}>\mathrm{Zn}>\mathrm{Cr}$. The potential ecological risk index of $\mathrm{Cr}, \mathrm{Cu}, \mathrm{Ni}, \mathrm{Pb}$ and $\mathrm{Zn}$ in 10 stations are lower than 40, which means a low potential risk in Sapanca Lake basin. In addition, $\mathrm{Cd}$ is the main ecological risk factor, ranging from 370.61 to 545.11, because $\mathrm{E}_{\mathrm{r}}$ values of $\mathrm{Cd}$ are far greater than $\mathrm{Cr}$, $\mathrm{Cu}, \mathrm{Ni}, \mathrm{Pb}$ and $\mathrm{Zn}$. As is the second dominant ecological risk factor, ranging from 122.91 to 141.46 . Cd has

Table 7. Potential ecological risk of heavy metals in Sapanca Lake basin.

\begin{tabular}{|c|c|c|c|c|c|c|c|c|}
\hline \multirow{2}{*}{ Stations } & \multicolumn{7}{|c|}{$\mathrm{E}_{\mathrm{r}}$} & \multirow{2}{*}{ RI } \\
\hline & As & $\mathrm{Cd}$ & $\mathrm{Cr}$ & $\mathrm{Cu}$ & $\mathrm{Ni}$ & $\mathrm{Pb}$ & $\mathrm{Zn}$ & \\
\hline 1 & 141.46 & 456.83 & 1.10 & 2.93 & 4.72 & 14.89 & 0.98 & 622.91 \\
\hline 2 & 130.95 & 401.30 & 0.85 & 2.92 & 4.28 & 14.48 & 0,99 & 555.76 \\
\hline 3 & 128.92 & 370.61 & 0.89 & 3.51 & 4.26 & 15.63 & 1.13 & 524.94 \\
\hline 4 & 135.01 & 391.70 & 0.71 & 3.18 & 2.92 & 14.88 & 1.01 & 549.42 \\
\hline 5 & 126.73 & 371.37 & 0.91 & 3.85 & 3.13 & 18.92 & 2.11 & 527.02 \\
\hline 6 & 122.91 & 396.58 & 1.25 & 3.13 & 3.51 & 17.80 & 1.21 & 546.39 \\
\hline 7 & 133.27 & 545.11 & 1.02 & 3.79 & 3.86 & 24.34 & 1.06 & 712.45 \\
\hline 8 & 136.42 & 413.70 & 1.21 & 3.60 & 4.21 & 14.11 & 1.24 & 574.49 \\
\hline 9 & 140.81 & 450.85 & 1.09 & 4.05 & 3.81 & 16.19 & 1.47 & 618.26 \\
\hline 10 & 138.65 & 476.16 & 0.94 & 3.51 & 4.11 & 15.47 & 1.32 & 640.16 \\
\hline Min & 122.91 & 370.61 & 0.71 & 2.92 & 2.92 & 14.11 & 0.98 & 524.94 \\
\hline Max & 141.46 & 545.11 & 1.25 & 4.05 & 4.72 & 24.34 & 2.11 & 712.45 \\
\hline Mean & 133.52 & 427.42 & 1.00 & 3.45 & 3.88 & 16.67 & 1.25 & 587.18 \\
\hline
\end{tabular}


serious potential ecological risk and As has considerable potential ecological risk in all stations. So, precautions should be taken against $\mathrm{As}$ and especially $\mathrm{Cd}$ in the soil and the effective pollution control for these metals should be implemented immediately.

\section{Conclusions}

Sapanca Lake is one of the most important sources of drinking water for the Marmara Region. Today, increasing environmental pollution and the threat of global warming have led to an increase in the number of studies on the protection and improvement of drinking water resources. Many factors affect drinking water resources. One of them is the structure and content of the basin soil. Drinking water resources in Turkey are examined at certain intervals and quality evaluation is carried out. However, it is not enough to protect the water resources. The aim of this study is to determine the heavy metal pollution in Sapanca Lake Basin and evaluate the ecological risks. At this point, improvements to the pollutants that will affect the quality of drinking water and a basic data set for model and projection studies for the protection of drinking water resources will be presented.

Within the scope of this study, the concentrations of heavy metals were determined in the soil samples that were taken seasonally. Soil samples were digested by the BCR sequential extractions methods to examine the chemical forms of heavy metals. The results of this study are summarized as follows.

As total concentrations of heavy metals are examined, the concentrations of $\mathrm{Al}$ and $\mathrm{Fe}$ are far greater than the other metals, because the soil of Sapanca Lake basin is very rich in terms of these elements that originated from crustal. The mean concentrations of other metals were determined to be $\mathrm{Zn}>\mathrm{Ba}>\mathrm{As}>\mathrm{Ni}>\mathrm{Cr}>\mathrm{Pb}>\mathrm{Cu}>\mathrm{Co}>\mathrm{Cd}$. Also, heavy metals are mainly found in the residual fraction at all stations. The relationship between the heavy metals in the soil was identified and the significant and positive correlation is observed between $\mathrm{Al}$ and $\mathrm{Fe}\left(\mathrm{r}^{2}=0.996\right)$, As and $\mathrm{Cd}\left(\mathrm{r}^{2}=0.925\right)$ and $\mathrm{Ni}$ and $\mathrm{Cr}\left(\mathrm{r}^{2}=0.903\right)$. According to $\mathrm{RAC}, \mathrm{As}, \mathrm{Ba}$ and $\mathrm{Cd}$ indicate a medium risk in terms of availability of the heavy metals in the environment. $\mathrm{Co}, \mathrm{Pb}$ and $\mathrm{Zn}$ mostly indicate a medium risk and this issue can turn into a medium risk at all stations in the near future. $\mathrm{Cd}$ has serious potential ecological risk and As has considerable potential ecological risk at all stations.

\section{Acknowledgements}

The authors thank the The Scientific And Technological Research Council Of Turkey for their financial support (Project No. 115Y357).

\section{References}

1. SUNGUR A., Metal analysis in soil samples taken from the eruption basin by sequential extraction method. Canakkale Eighteen March University, PhD Thesis, 2013.

2. NEMATI K., ABUBAKAR N.K., ABAS M., SOBHANZADEH E., Speciation of heavy metals by modified BCR sequential extraction procedure in different depths of sediments from Sungai Buloh, Selangor, Malaysia, J. Hazard. Mater. 192, 402, 2011.

3. KELEPERTZIS E., Accumulation of heavy metals in agricultural soils of mediterranean: insights from Argolida basin, Peloponnese, Greece. Geoderma. 221-222, 82, 2014.

4. OVES M., KHAN M.S., ZAIDI A., AHMAD E., Soil contamination, nutritive value and human health risk assessment of heavy metals: an overview. Toxicity of Heavy Metals to Legumes and Bioremediation. Springer, Wien, 1, 2012.

5. WU J., LU J., Lİ L., MINN X., LUO Y., Pollution, ecologicalhealth risks, and sources of heavy metals in soil of the northeastern Qinghai-Tibet Plateau. Chemosphere, 201, 234, 2018.

6. OYEYIOLA A.O., OLAYINKA K.O., ALO B.I., Comparison of three sequential extraction protocols for the fractionation of potentially toxic metals in coastal sediments. Environ Monit Assess. 172, 319, 2011.

7. TASHAKOR M., YAACOB W.Z.W., MOHAMAD, H., GHANI A.A., SAADATI N., Assessment of selected sequential extraction and the toxicity characteristic leaching test as indices of metal mobility in serpentinite soils. Chem. Spec. Bioavailab. 26, 139, 2014.

8. ZONG Y.T., XIAO Q., LU S.G. Chemical fraction, leachability, and bioaccessibility of heavy metals in contaminated soils, northeast china. Env. Sci. and Pol. Res. 23 (23), 24107, 2016.

9. ZHANG P., QIN C., HONG X., KANG G., QIN M., YANG D., PANG B., LI Y., HE J., DICK R. P., Risk assessment and source analysis of soil heavy metal pollution from lower reaches of Yellow River irrigation in China. Science of the Total Environment 633, 1136, 2018.

10. PENG C., WANG M., CHEN W., CHANG A.C., CRITTENDEN J.C. Mass balance-based regression modeling of $\mathrm{Cd}$ and $\mathrm{Zn}$ accumulation in urban soils of Beijing. J. Env. Sci, 53, 99, 2017.

11. YE H., LI G., YUAN X., ZHENG M., Fractionation and bioavailability of trace elements in Wuyi rock tea garden soil, Polish Journal of Environmental Studies. 27 (1), 421, 2018.

12. WANG Z., HONG C., XING Y., WANG K., LI Y., FENG L., MA S., Spatial distribution and sources of heavy metals in natural pasture soil around copper-molybdenum mine in northeast China. Ecotoxicology and Environmental Safety 154, 329, 2018.

13. XU Y., DAI S., MENG K.,WANG Y., REN W., ZHAO L., YINGTENG C.P., Occurrence and risk assessment of potentially toxic elements and typical organic pollutants in contaminated rural soils. Science of the Total Environment 630, 618, 2018.

14. BAIG J.A., KAZI T.G., ARAIN M.B., SHAH A.Q., SARFRAZ R.A., AFRIDI H.I., Arsenic fractionation in sediments of different origins using BCR sequential and single extraction methods. J. Hazard. Mater. 167, 745, 2009.

15. FERNÁNDEZ-ONDOÑO E., BACCHETTA G., LALLENA A.M., NAVARRO F.B., ORTIZZ I., JIMÉNEZ 
M.N., Use of BCR sequential extraction procedures for soils and plant metal transfer predictions in contaminated mine tailings in Sardinia. J. of Geochem. Exploration, 172, 133, 2017.

16. RODRIGUEZ L., RUIZ E., ALONSO-AZCARATE J., RINCÓN J., Heavy metal distribution and chemical speciation in tailings and soils around a $\mathrm{Pb}-\mathrm{Zn}$ mine in Spain. J. Environ. Manag. 90, 1106, 2009

17. KAHKHA M.R. R., BAGHERI S., NOORI S., PIRI J., JAVAN S., Examining Total Concentration and Sequential Extraction of Heavy Metals in Agricultural Soil and Wheat, Polish Journal of Environmental Studies, 26 (5), 2021, 2017.

18. ISEN H. Sakarya D-100 highway roadway dusted with some heavy metals by sequential extraction method (BCR), Sakarya University, M.Sc. Thesis, 2012.

19. ZEMBERYOVA M., BARTEKOVA J., HAGAROVA I., The Utilization of modified bcr three-step sequential extraction procedure for the fractionation of $\mathrm{Cd}, \mathrm{Cr}, \mathrm{Cu}$, $\mathrm{Ni}, \mathrm{Pb}$ and $\mathrm{Zn}$ In soil reference materials of different origins. Talanta, 70, 973, 2006.

20. NANNONI F., PROTANO G., RICCOBONO F., Fractionation and geochemical mobility of heavy elements in soils of a mining area in northern Kosovo. Geoderma, 161, 63, 2011.

21. YUAN X.Y., LI T.Y., LI J.Z., YE H.M., GE M.X. Origin and risk assessment of potentially harmful elements in river sediments of urban, suburban, and rural areas. Polish Journal of Environmental Studies. 22 (2), 599, 2013.

22. GAO H., BAI J., XIAO R., LIU P., JIANG W., WANG J., Levels, sources and risk assessment of trace elements in wetland soils of a typical shallow freshwater lake, China. Stoch Environ Res Risk Assess, 27, 275, 2013.

23. CHENG S., LIU G., ZHOU C., SUN R., Chemical speciation and risk assessment of Cadmium in soils around a typical coal mining area of China. Ecotoxicology and Environmental Safety, 160, 67, 2018.

24. YINGJUN S., YINGJUN S., Ecological risk evaluation of heavy metal pollution in soil based on simulation. Polish Journal of Environmental Studies, 26 (4), 1693, 2017.

25. ZHANG H., WU C., GONG J., YUAN X., WANG Q., PEI W., LONG T., QIU J., Zhang H., Assessment of heavy metal contamination in roadside soils along the ShenyangDalian highway in liaoning province, China. Polish Journal of Environmental Studies, 26 (4), 1539, 2017.

26. SINGH K.P., MOHAN D., SINGH V.K., MALIK A., studies on distribution and fractionation of heavy metals in Gomti River sediments - A tributary of the Ganges, India. Journal Of Hydrology. 312 (1-4), 14, 2005.
27. YALCIN N., SEVINC V., Heavy metal contents of Lake Sapanca. Turk J Chem, 25, 521, 2001.

28. TESSIER A., CAMPEL P.G.C., BISSON M., Sequential extraction procedure for the speciation of particulate trace metals. Anal. Chem, 51, 844, 1979.

29. CEVIK F, GOKSU M.Z.L, DERICI O.B., An assessment of metal pollution in surface sediments of Seyhan Dam by using enrichment factor, geoaccumulation index and statistical analyses. Environmental Monitoring Assessment, 152, 309, 2009.

30. WEDEPOHL K.H., The composition of the upper earth's crust and the natural cycles of selected metals in natural raw materials, natural resources, in: E. Merian (Ed.), Metals and their Compounds in Environment: Occurrence, Analysis and Biological Relevance, VCH, New York, 3, (17) 1991.

31. FERNANDES H.M., Heavy metal distribution in sediments and ecological risk assessment: the role of diagenetic processes in reducing metal toxicity in bottom sediments, Environmental Pollution, 97, 3, 317, 1997.

32. BARONA A., ARANGNIZ I., ELIAS A., Assessment of metal extraction, distribution and contamination in surface soils by a 3 -step sequential extraction procedure, Chemopshere, 39, 11, 1911, 1999.

33. KARAK T., ABOLLINO O., BHATTACHARYYA P., DAS K.K., PAUL R.K. Fractionation and speciation of arsenic in three tea gardens soil profiles and distribution of as in different parts of tea plant (camellia sinensis 1.). Chemosphere. 85 (6), 948, 2011.

34. PERIN G., CRABOLEDDA L., LUCCHESE M., CIRILLO R., DOTTA L., ZANETTE M.L., ORIO A.A., Heavy metal speciation in the sediments northern Adriatic Sea - A New Approach For Environmental Toxicity Determination, Heavy Met. Environ. 2, 454, C.K, 1985.

35. HAKANSON L. An Ecological risk index for aquatic pollution control a sedimentological approach. Water Res. 14, 975, 1980.

36. OGUNKUNLE C.O., FATOBA P.O., Pollution loads and the ecological risk assessment of soil heavy metals around a mega cement factory in southwest Nigeria. Pol. J. Environ. Stud. 22 (2), 487, 2013.

37. TUREKIAN K.K., WEDEPOHL K.H., Distribution of the elements in some majör units of the earth's crust. Bull. Geol. Soc. Am. 72, 175, 1961.

38. GUO W., LIU X., LIU Z., LI G., Pollution and potential ecological risk evaluation of heavy metals in the sediments around Dongjiang Harbor, Tianjin. Int Soc Environ Inf Sci 2, 729, 2010. 
